\title{
Carbon storage versus fossil fuel substitution: a climate change mitigation option for two different land use categories based on short and long rotation forestry in India
}

\author{
Meenakshi Kaul • G. M. J. Mohren • V. K. Dadhwal
}

Received: 20 November 2009 / Accepted: 25 March 2010 /

Published online: 8 April 2010

(C) The Author(s) 2010. This article is published with open access at Springerlink.com

\begin{abstract}
Short rotation bioenergy crops for energy production are considered an effective means to mitigate the greenhouse effect, mainly due to their ability to substitute fossil fuels. Alternatively, carbon can be sequestered and stored in the living biomass. This paper compares the two land use categories (forest land and non-forest land) for two management practices (short rotation vs. long rotation) to study mitigation potential of afforestation and fossil fuel substitution as compared to carbon storage. Significant carbon benefit can be obtained in the long run from using lands for growing short rotation energy crops and substituting fossil fuels by the biomass thus produced, as opposed to sequestering carbon in the biomass of the trees. When growth rates are high and harvest is used in a sustainable manner (i.e., replanting after every harvest), the opportunities for net carbon reductions appear to be fossil fuel substitution, rather than storage in ecosystem biomass. Our results suggest that at year 100 a total of $216 \mathrm{Mg} \mathrm{C} \mathrm{ha}^{-1}$ is sequestered for afforestation/ reforestation using long rotation sal (Shorea robusta Gaertn.f) species, as opposed to offset of $412 \mathrm{Mg} \mathrm{C} \mathrm{ha}^{-1}$ for carbon storage and fossil fuel substitution for short rotation poplar (Populus Deltoides Marsh) plantations. The bioenergy option results in a continuous stream of about $3 \mathrm{MgC} \mathrm{ha}^{-1} \mathrm{yr}^{-1}$ of carbon benefits per year on forest land and $4 \mathrm{Mg} \mathrm{C} \mathrm{ha}^{-1} \mathrm{yr}^{-1}$ on non-forest land. Earlier studies have shown that in India waste land availability for establishing energy plantations is in the range of 9.6 to 36.5 Mha. Thus, using the $758 \mathrm{Tg}$ biomass per year generated from 9.6 Mha waste land gives a mitigation potential in the range of 227 to $303 \mathrm{Tg} \mathrm{C}$ per year for carbon storage and fossil fuel substitution from poplar plantation for substituting coal based power generation. Depending upon the land
\end{abstract}

M. Kaul ( $\square) \cdot$ G. M. J. Mohren

Forest Ecology and Forest Management Group (FEM), Centre for Ecosystem Studies, Wageningen

University, P. O. Box 47, NL-6700 AA Wageningen, The Netherlands

e-mail: kaul_2000@rediffmail.com

G. M. J. Mohren

e-mail: frits.mohren@wur.nl

V. K. Dadhwal

Indian Institute of Remote Sensing (IIRS), 4 Kalidas Road, Dehradun UA-248001, India

e-mail:vkdadhwal@iirs.gov.in 
availability for plantation, the potential for energy generation is in the range of 11,370 PJ, possibly amounting to a bioenergy supply of $43 \%$ of the total projected energy consumption in 2015. Further studies are needed to estimate the mitigation potential of other species with different productivities for overall estimation of the economic feasibility and social acceptability in a tropical country like India.

Keywords Bioenergy · Fossil fuel substitution · Mitigation · Short rotation crops · Afforestation

\section{Introduction}

Evidence of climate change linked to human-induced increase in greenhouse gas (GHG) concentrations is well-documented in international studies (IPCC 2001, 2007). Due to rapid economic growth and large population size, energy consumption is projected to increase at the highest rates in developing countries, largely in China and India. This increase in energy consumption will result in higher greenhouse gas emissions (GCB 2008; Takeshita 2009), associated with fossil fuel use. Additional greenhouse gas emissions originate mostly from land-use change, with deforestation in tropical countries accounting for roughly $20 \%$ of the anthropogenic carbon (C) emissions (IPCC 2007). To contribute to reduction of GHG emissions, and to partly offset deforestation, the Kyoto protocol (KP) explicitly considered reforestation and afforestation activities for carbon sequestration accounting (IPCC 2007). Terrestrial carbon dynamics are typically characterized by long periods of slow carbon uptake, interrupted by short periods of rapid and large carbon release during disturbances or harvest. Depending on the stage of stand development, individual stands can be either carbon sources or carbon sinks. Theoretically, maximum carbon storage (saturation) in a forested landscape is attained when all stands are in old-growth state, but this rarely occurs as natural or human disturbances maintain stands of various ages within the forest landscape. For an average hectare of forested land worldwide, between 50 and $120 \mathrm{Mg}$ $\left(1 \mathrm{Mg}=10^{6} \mathrm{~g}\right)$ of carbon are accumulated in aboveground biomass (IPCC 2000). The total aboveground forest $\mathrm{C}$ stock in the biosphere is estimated to be around $320-360 \mathrm{Pg}$ (1 Pg= $10^{15} \mathrm{~g}$; Dixon et al. 1994; FAO/FRA 2006; IPCC 2000).

Forest mitigation options include reducing emissions from deforestation and forest degradation, enhancing the sequestration rate in existing and new forests, providing wood fuels as a substitute for fossil fuels, and providing wood products for more energy-intensive materials (IPCC 2007). The fourth assessment report of the Intergovernmental Panel on Climate Change (IPCC) concludes that for mitigation of climate change several types of measures need to be considered simultaneously (IPCC 2007). One of the measures that are receiving increased attention from scientists, policymakers and governments is land management to protect and reforest forest land either by direct forest management, or by establishment of fast growing plantations to produce biomass that can be substituted for fossil fuels in energy production. Both these mitigation options are likely to enhance the competitive advantage of woody biomass energy over fossil fuels as they may store carbon while at the same time replace emissions from fossil fuel use (Marland and Schlamadinger 1997; Berndes et al. 2003; Walker et al. 2009). Marland and Schlamadinger (1997) suggested that direct carbon sequestration is favoured under low growth and low conversion efficiency (slow growing, long-lived trees), while fossil fuel substitution is favoured under high growth and high conversion efficiency (high production, short-rotation plantations). In line with this, Baral and Guha (2004) showed that significant carbon benefit 
can be obtained by substituting for coal or gasoline by biomass derived from short rotation woody crops, as compared to sequestering carbon in standing trees. Baral and Guha (2004) indicate that the use of tree biomass for fossil fuel substitution can be a longer-term measure because harvesting and replanting in a given piece of land can be carried out in perpetuity, while storage of carbon in biomass through photosynthetic uptake is limited to the build up of biomass in the forest, which approaches a maximum at high forest age, when natural decomposition equals biomass formation. Although both the approaches i.e., carbon storage through accumulated tree growth and biomass use by substituting fossil fuels, seem to be conflicting, both offer the prospect of substantially contributing to overall net carbon dioxide $\left(\mathrm{CO}_{2}\right)$ emissions reduction, by different mechanisms.

Biomass from forestry can contribute $12-74$ EJ $\left(1 \mathrm{EJ}=10^{18} \mathrm{~J}\right)$ per year to energy consumption, with a mitigation potential roughly equal to 0.4-4.4 $\mathrm{Pg} \mathrm{CO}$ per year depending on the assumption whether biomass replaces coal or gas in power plants (IPCC 2007). Biomass in India already accounts for $31 \%$ of the total primary energy use, while fossil fuels account for about 67\% (Gupta and Ravindranath 1997), with solar power and wind energy accounting for the remainder. Biomass energy includes fuel wood, crop residues and cow dung, accounting for $63 \%, 28 \%$ and $9 \%$ of the total, respectively (Gupta and Ravindranath 1997).

Forest plantations established exclusively for the purpose of energy production are becoming more common, and plantations with multiple end uses may provide wood both for generating fuel and for other purposes (FAO 2008). A recent FAO study by Carle and Holmgren (2008) surveyed 61 countries representing 95\% of all the planted forests; they indicated that potential industrial wood production from planted forests in 2005 was 1.2 billion $\mathrm{m}^{3}$ or two-thirds of the overall industrial wood production in that year. Establishment of plantations on degraded and waste lands is one of the best and most promising options for halting deforestation and increasing carbon storage in trees. Reforestation of non-forest lands will prevent further land degradation and can provide a continuous supply of biomass for energy use, replacing fossil fuels and reducing net $\mathrm{C}$ emissions.

Since the implementation of social forestry and large-scale afforestation programmes, fuel wood production has gradually shifted from forests towards non-forests areas. A lot of fuel wood extraction now takes place along roadside, canals and farm forestry, gradually decreasing pressure on forests for wood removal in India. In India, trees outside forests have a major contribution in meeting timber and fuel wood needs. The total growing stock of wood in India is estimated to be 6.4 billion $\mathrm{m}^{3}$, of which 4.8 billion $\mathrm{m}^{3}$ are found in forests and 1.6 billion $\mathrm{m}^{3}$ outside the officially recorded forest area (FSI 2003). This information highlights the need to consider both forest areas and non-forest areas in models of carbon mitigation studies. The objective of this study is to compare the carbon mitigation potential of afforestation and fossil fuel substitution for two land use categories (forest land and non-forest land) and two management practices (short vs. long rotation).

\section{Methods and materials}

The CO2FIX v. 3.1 stand level simulation model is a tool which quantifies the carbon stocks and fluxes in forest biomass, the soil organic matter and the wood products chain, essentially using a simple bookkeeping approach (Masera et al. 2003; Schelhaas et al. 2004). The CO2FIX model consists of four modules, i.e. biomass, soil carbon, wood products and bioenergy (the latter being new to CO2FIX v. 3.1) (Fig. 1). The biomass 


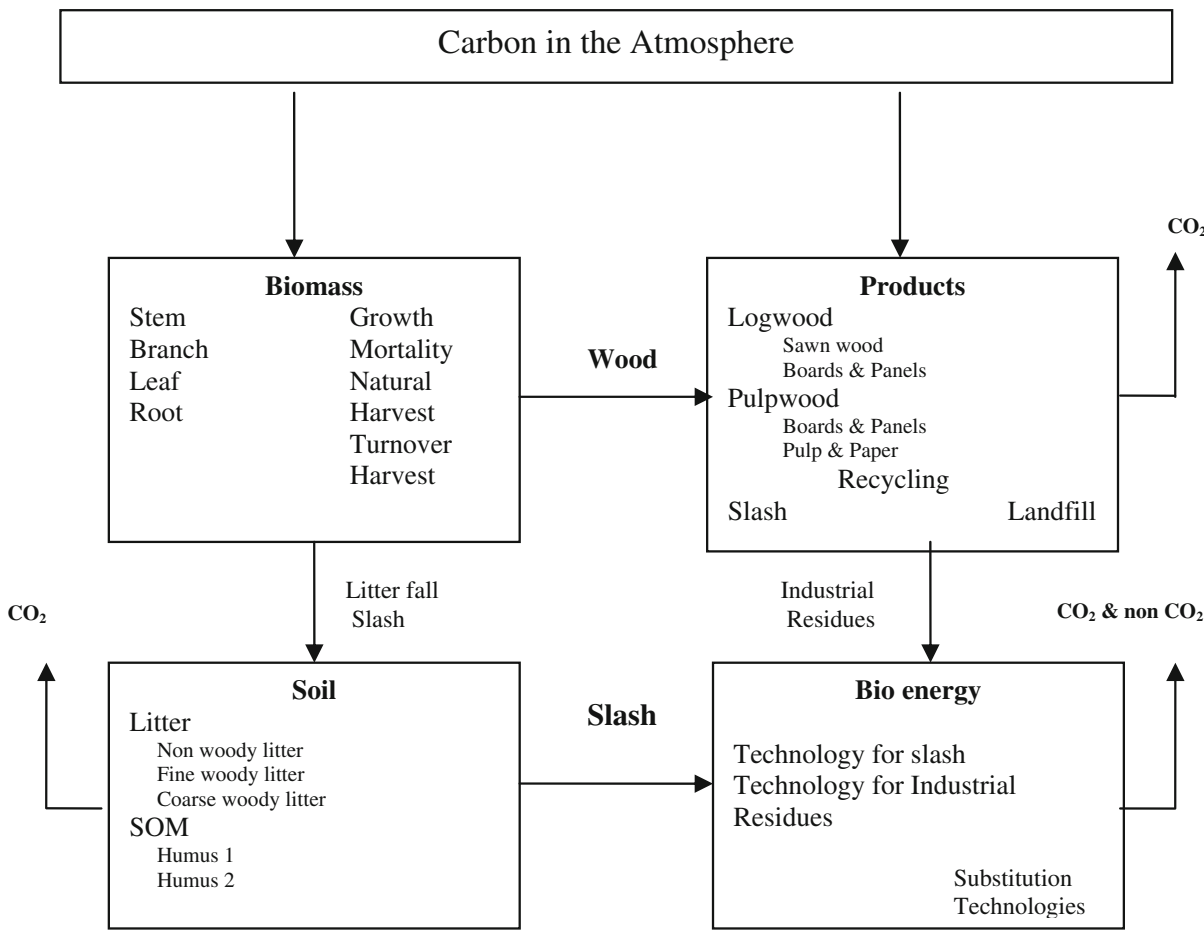

Fig. 1 Structure of CO2FIX v. 3.1 model, including major compartments used in each module, processes affecting the compartments (right hand side in the boxes), major flows between modules and fluxes of $\mathrm{CO}_{2}$ from modules to the atmosphere

module converts volumetric net annual increment data to the annual carbon stock of the biomass compartment. Turnover and harvest parameters drive the fluxes from biomass to soil. The soil module of CO2FIX takes litter material generated in the biomass module including natural mortality, management mortality, and logging slash and separates it into non-woody litter (foliage and fine roots), fine woody litter (branches and coarse roots) and coarse woody litter (stems and stumps). Each of these litter compartments is decomposed in two steps. In the first step a fractionation rate determines the proportion of each component released to the decomposition compartments in a time step. For the compartment of nonwoody litter, this rate is equal to 1 which means that all of its contents are released in one time step, whereas for the woody litter compartments this rate is smaller than 1 . In the second step, the model uses assumed chemical compositions (i.e., extractives, cellulose, or lignin) of each component to assign a specific decomposition rate, which determines the proportional loss of its contents in a time step (Liski et al. 2005). Default values are available for the chemical composition of components in the soil module. The soil module uses climate data about precipitation, evapotranspiration and mean monthly temperatures. Initial soil and carbon data were derived from the procedure as reported by Masera et al. (2003). The model is user friendly and provides a number of examples of required input data for a variety of forest management scenarios. Climate data was used from http://www. indiastat.com. CO2FIX can calculate degree days (above zero, $0^{\circ}$ ) and potential evapotranspiration from mean monthly temperatures.

Previously, we used the CO2FIX model for estimating the carbon stocks and carbon sequestration potential of some short and long rotation species under different management 
scenarios for India (Kaul et al. 2010). For the purpose of this paper, we use the bioenergy module of the CO2FIX model, which calculates the carbon mitigation achieved by substituting biomass for fossil fuels. The model simulations were calibrated with inventory data for sal (Shorea robusta Gaertn.f) as representative of long rotation forests and poplar (Populus deltoides Marsh) as short rotation plantation forests. For further details on the CO2FIX model, see Masera et al. (2003); Schelhaas et al. (2004); for a more detailed representation of the parameter values for the above mentioned species in India, see Kaul et al. (2010). The full CO2FIX model is freely available from the web at http://www.efi.int/ projects/casfor, together with a large number of examples and case studies.

The bioenergy module calculates C-equivalent greenhouse gas flow differences between biomass generated energy and energy derived from fossil fuel. Two subroutines are included in the model: slash biomass substitution technologies and industrial residue substitution technologies. The slash biomass routine uses the part of the slash that remains in the forest after thinning or harvesting short plantations aimed at replacing fossil fuelbased energy production. The industrial residues routine uses industrial woody residues generated from the production of other wood products. For each technology, either traditional (fossil fuel) or substitution (slash and industrial residues), defaults values for efficiency, emission factors, heating values, technology emission factors, and global warming potential of the greenhouse gases are available in the model. The specific values used for the parameterization of the bioenergy module are shown in Table 1.

It is worth mentioning that the bioenergy module does not calculate the carbon stock per se; it calculates the effect of using wood or wood waste for the generation of energy. Thus, fossil fuels are replaced by $\mathrm{CO}_{2}$ neutral fuels, and can thus be regarded as avoided emission. When harvesting is followed by replanting, the net $\mathrm{CO}_{2}$ emissions from bioenergy technologies are zero. Therefore, their associated $\mathrm{CO}_{2}$ emissions factors should also be zero. The substitution of fossil fuels by biomass leads to a permanent green house gas mitigation.

We have defined four scenarios in order to draw comparisons among alternative forest management strategies. These scenarios are as follows:

(a) establishment of long-rotation species on forest lands;

(b) short rotation forestry starting on forest lands

(c) establishment of long-rotation species on non-forest lands;

(d) short rotation forestry starting on non-forest lands;

Table 1 Main parameters of the bio energy module to compare current technologies using coal power plant with biomass combustion power plant

\begin{tabular}{llc}
\hline & $\begin{array}{l}\text { Current technology } \\
\text { (Coal based power plant) }\end{array}$ & $\begin{array}{l}\text { Alternative technology } \\
\text { (Biomass combustion power plant) }\end{array}$ \\
\hline Energy content $(\mathrm{MJ} / \mathrm{Kg})$ & 28 & 15 \\
Efficiency $(\%)$ & 33 & 24 \\
$\mathrm{CO} 2$ emissions (Kg gas/Kg fuel) & 2.425 & 0 \\
N2O emissions (g/Kg fuel) & .04 & .06 \\
CH4 emissions $(\mathrm{g} / \mathrm{Kg}$ fuel) & .02 & .48 \\
CO emissions $(\mathrm{g} / \mathrm{Kg}$ fuel) & .24 & 3.6 \\
TNMOC emissions (g/Kg fuel) & 0.00 & .72 \\
\hline
\end{tabular}


In the scenarios (a) and (b), we assume that forestry is initiated by harvest at time 0 of one ha of forest which contained biomass carbon of $156 \mathrm{Mg} \mathrm{ha}^{-1}$ before the final cut. In scenarios (c) and (d), we assume that the forestry is initiated on a non-forest land which was without vegetation or barren for the last 20-30 years. The present study employs the soil and litter carbon uptakes as prescribed by the CO2FIX model run for 20 years without biomass. The scenarios (a) and (c) refer to establishment of trees on forest- and non-forest land, in which trees are planted, protected and allowed to grow without final cut or harvesting, resulting in accumulation of carbon stock in standing trees over the rotation. Thinning is performed at regular intervals as per the prescribed management practices (Tewari 1995). The forest is left to its natural dynamics and the biomass removed from the thinning is assumed to be collected and used as fuel wood by local villagers.

The scenarios (b) and (d) refer to planting of short rotation species on forest and nonforest lands with harvesting and replanting on regular basis and using harvested wood to substitute for fossil fuels. A constant growth rate of $8 \mathrm{Mg} \mathrm{C} \mathrm{ha}^{-1} \mathrm{yr}^{-1}$ is considered until the time of harvest for poplar (Kaul et al. 2010). Under fossil fuel substitution, mitigation occurs through the use of slash and industrial wood residues to replace coal for electricity generation in coal fired plant, which is the most commonly used source of electricity production in rural India. The CO2FIX model was run for all four scenarios and the amount of carbon sequestered versus the avoided emission via substitution of fossil fuel use was compared over a period of 100 years.

\section{Results}

Figures 2 and 3 show the cumulative increase in $\mathrm{C}$ stocks in various pools over 100 years for carbon sequestration and fossil fuel substitution in forest and non-forest lands. The comparison of simulations for each scenario is presented below in detail.

The carbon storage in forest ecosystem (trees + soil) on forest and non-forest lands varied depending on the species and on the management scenario (Figs. $2 \& 3$ ). The long term (100 years) average carbon stock in tree biomass was higher for long rotation forests as compared to short rotation plantations, irrespective of land use type. The long term average carbon storage for long rotation species was highest $\left(141 \mathrm{Mg} \mathrm{C} \mathrm{ha}^{-1}\right)$ on forest lands as compared to non-forest lands (106 $\mathrm{Mg} \mathrm{C}^{-1}$ ) (Fig. 2a \& b).

Carbon sequestration in soil and litter on forest lands, as simulated by the model, is higher both for short as well as long rotation forests (Fig. 3a \& b). The long term average carbon stock in tree biomass and soil including litter was $81 \mathrm{Mg} \mathrm{Cha}^{-1}$ and $45 \mathrm{Mg} \mathrm{C} \mathrm{ha}^{-1}$ on forest and non-forest lands for poplar plantations. On forest lands, the soil carbon displayed a rapid decrease in the initial 10 years from $118 \mathrm{Mg} \mathrm{C} \mathrm{ha}^{-1}$ followed by a slow recovery and later stabilized at $60 \mathrm{Mg} \mathrm{Cha}^{-1}$. This could be due to rapid decomposition of litter and soil resulting in net carbon loss to the atmosphere for initial 10 years and slowly stabilizes with subsequent re-growth. Carbon sequestration in soil and litter through afforestation is higher for long rotation as compared to short rotation species. One possible explanation is that the disturbance due to repeated site preparation and harvesting at regular intervals enhances decomposition of soil and litter resulting in low carbon content when short rotation crops are used.

The Fig. 2a \& b for long rotation species suggests that the carbon accumulation rate in above ground biomass is linear but declines due to saturation effect. This saturation effect could be avoided if the forest is harvested periodically and a young, fast growing forest is maintained. The net carbon mitigation potential is strongly dependent on the multitude of 


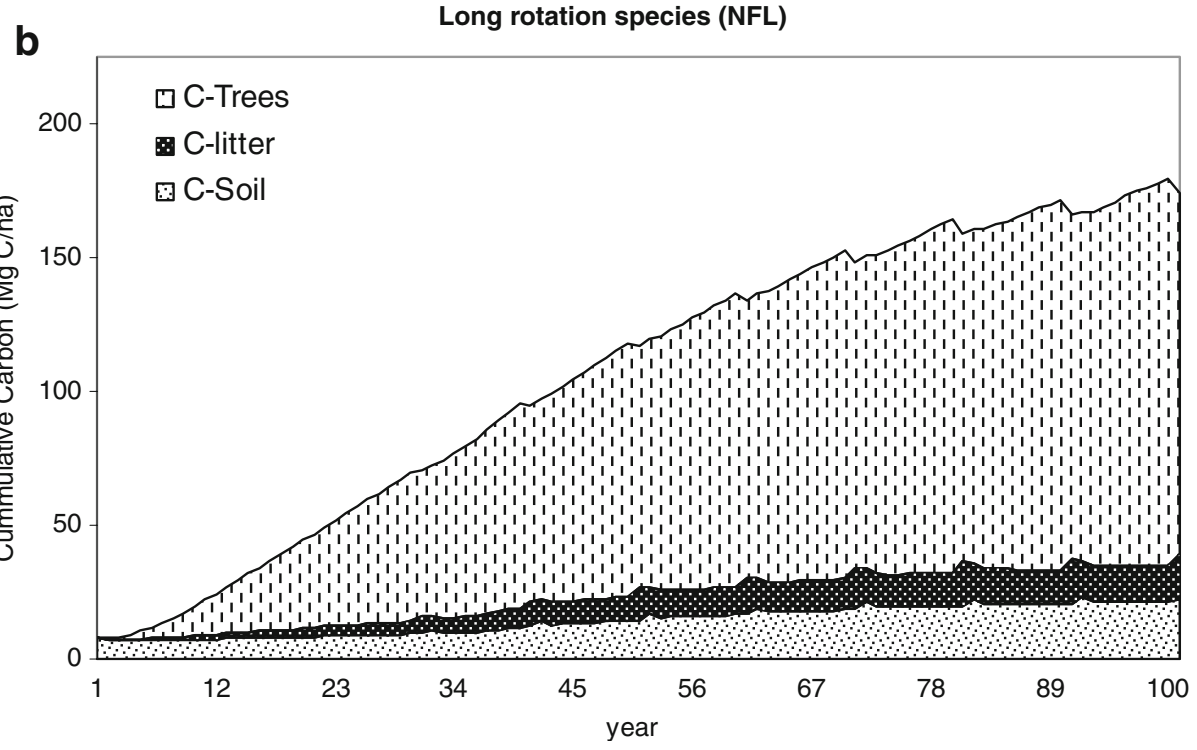

Fig. 2 Cumulative carbon sequestered in tree, soil and product pools for (a) Forest land (FL) and (b) Nonforest land (NFL)

parameters that ultimately define the displacement efficiency of bio-fuels. Figure $4 \mathrm{a} \& \mathrm{~b}$ show the net yearly carbon benefit for short and long rotation species, respectively on forest and non-forest lands since the start of simulation till 100 year period. For short rotation species, the amount of carbon offset increases linearly with time since biomass is continuously harvested and replanted and used to generate energy, and hence under suitable conditions the substitution of fossil fuel can continue forever. On forest lands, the carbon balance is negative in the beginning (due to enhanced decomposition) but it turns positive after about 34 and 14 years respectively, for long rotation sal forests and short rotation 


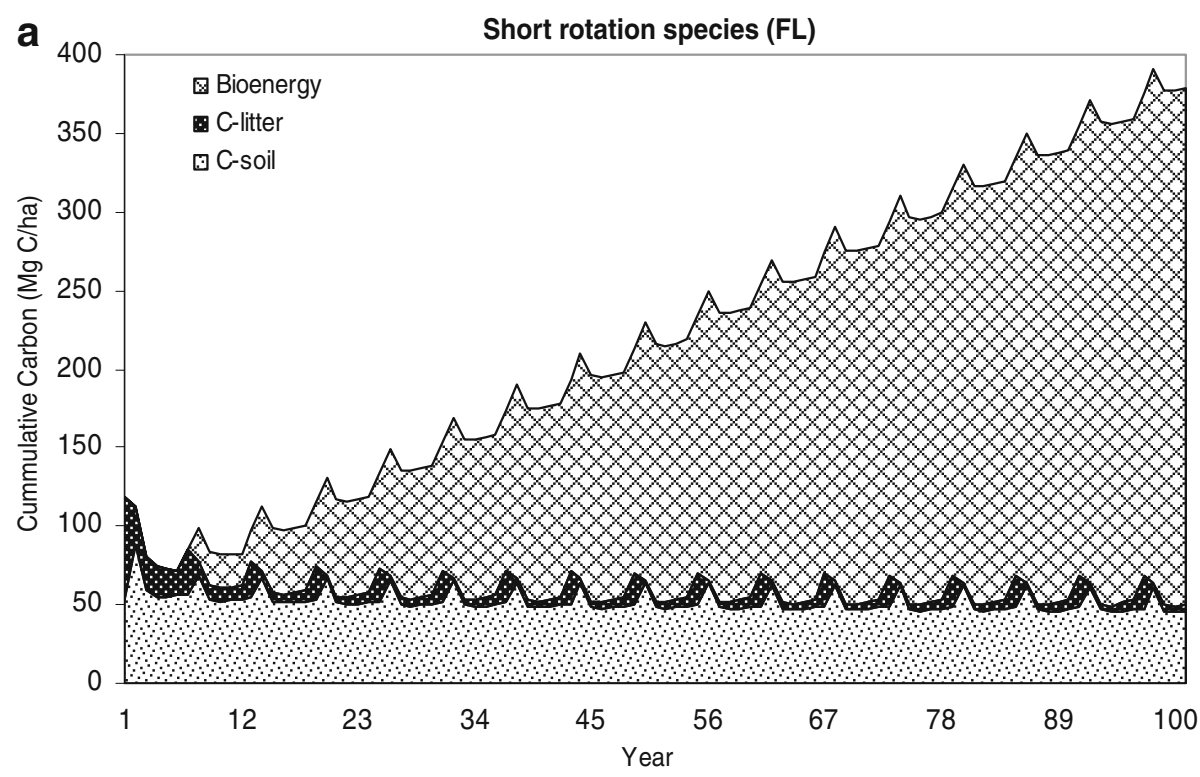

b

Short rotation species (NFL)

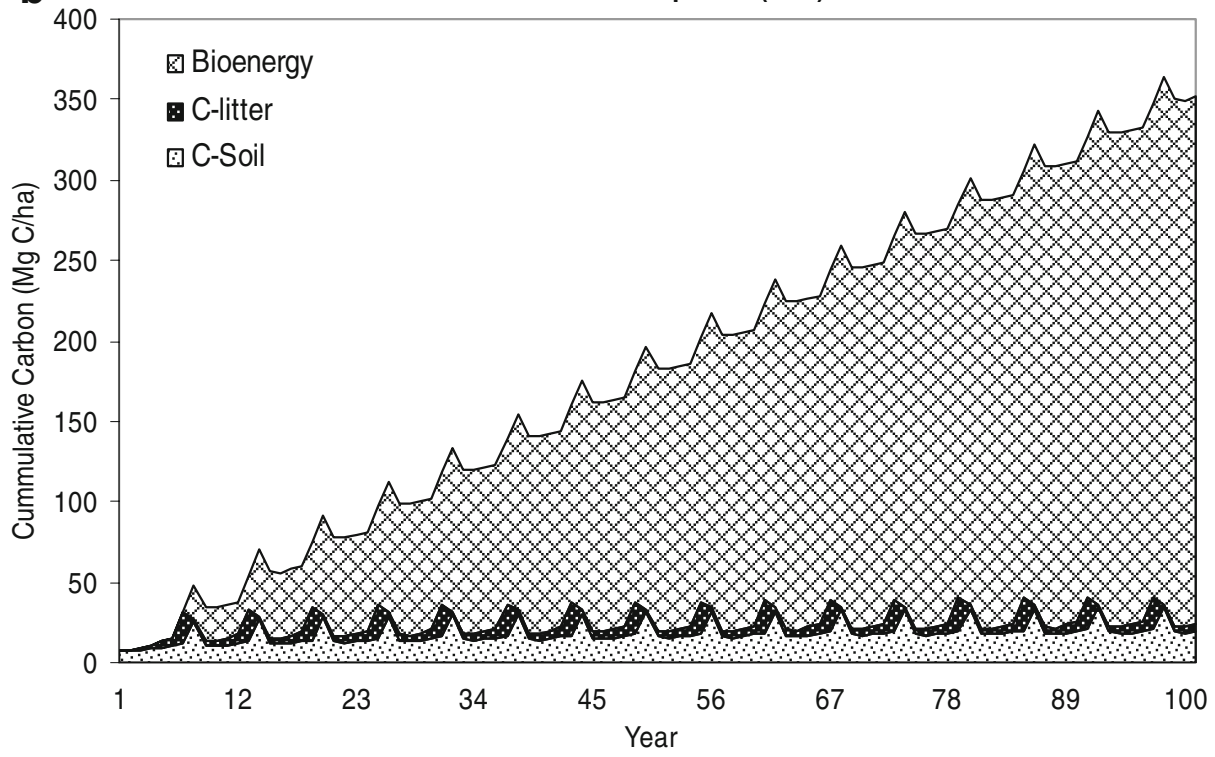

Fig. 3 Cumulative carbon offset for bio-fuel/coal substitution for poplar for (a) Forest Land (FL) and (b) Non-forest land (NFL)

poplar species (Fig. 4a). On non-forest lands however, there is no initial decrease in soil carbon associated with decomposition and emission of carbon in both the species. At 6 years, the carbon sink attains a maximum value of $11 \mathrm{Mg} \mathrm{C} \mathrm{ha}^{-1} \mathrm{yr}^{-1}$ for short rotation poplar plantation on non-forest lands (Fig. 4b). After a transient period, the bioenergy option mitigates around $1 \mathrm{MgC} \mathrm{ha}^{-1} \mathrm{yr}^{-1}$ and $3 \mathrm{MgC} \mathrm{ha}^{-1} \mathrm{yr}^{-1}$ on forest land whereas it 
stabilizes at $2 \mathrm{MgC} \mathrm{ha}^{-1} \mathrm{yr}^{-1}$ and $4 \mathrm{MgC} \mathrm{ha}^{-1} \mathrm{yr}^{-1}$ on non-forest land, respectively for long rotation sal forests and short rotation poplar plantations.

Figure 5 compares the total carbon sequestered versus the total carbon offset through emission avoidance for short and long rotation forests for the period of 100 years. The carbon benefit at any time is highest for short rotation poplar plantation involving substitution of coal. This may be attributed to the high carbon sequestration rate and high energy conversion efficiencies. At any time the carbon benefit from land used only for
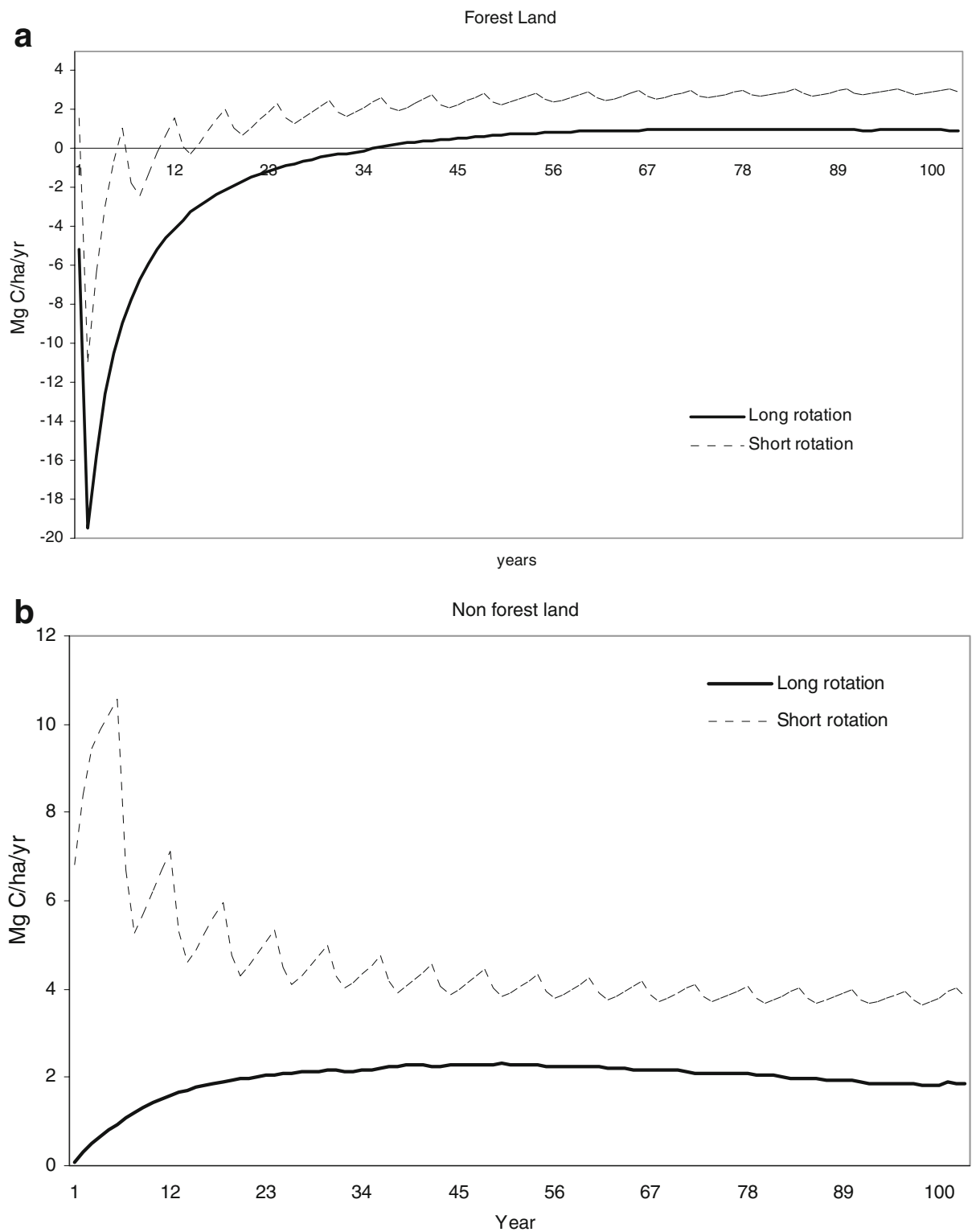

Fig. 4 Net yearly $\mathrm{C}$ mitigation potential ( $\mathrm{Mg} \mathrm{C} / \mathrm{ha} / \mathrm{yr})$ of sal afforestation and short rotation bio energy on (a) Forest land and (b) Non-forest land 
carbon storage is lower compared to fossil fuel substitution scenarios. At year 100 a total of $216 \mathrm{Mg} \mathrm{C} \mathrm{ha}{ }^{-1}$ is sequestered for afforestation/reforestation using long rotation sal species, as opposed to offset of $412 \mathrm{Mg} \mathrm{C}^{-1}$ for carbon storage and fossil fuel substitution for short rotation poplar plantations.

As mentioned earlier, we assume that biomass from short rotation poplar plantations is used for electric power generation, substituting coal based electricity generation. Biomass based electricity generated from a sustainable wood supply is a carbon neutral option for power generation leading to zero net emissions. Given that 1 dry $\mathrm{Mg}$ of wood replaces $0.67 \mathrm{Mg}$ of coal (Hooda and Rawat 2006), our model results suggest that $79 \mathrm{Mg} \mathrm{ha}^{-1} \mathrm{yr}^{-1}$ of wood biomass is available from short rotation plantation which could replace $53 \mathrm{Mg}$ of coal. Sudha et al. (2003) estimated that under different biomass demand scenarios, the total land available in India for biomass production ranges between 9.6 to 36.5 Mha. Thus, the potential biomass that can be acquired for generating bioenergy from 9.6 Mha land would be $758 \mathrm{Tg}\left(1 \mathrm{Tg}=10^{12} \mathrm{~g}\right)$ per year. The annual electricity generation potential $(1 \mathrm{Tg}=$ $1 \mathrm{TWh}$ of electrical power) would be $758 \mathrm{TWh}$. Hence every megawatt hour (MWh) of bioelectricity generated from biomass leads to a carbon emission reduction of 0.3 to $0.4 \mathrm{Mg}$ as compared to the use of fossil fuel (Hooda and Rawat 2006; Rawat and Kishan 2008). Thus, using short rotation plantations for electric power generation gives a mitigation potential in the range of 227 to $303 \mathrm{Tg} \mathrm{C}$ per year from carbon storage and fossil fuel substitution. The energy content of wood is considered as $15 \mathrm{GJ} \mathrm{Mg}^{-1}$ and thus the energy generation potential of poplar plantation generating $758 \mathrm{Tg}$ wood annually, would be 11,370 PJ. It is projected that the energy consumption in 2015 will be $26,527 \mathrm{PJ}$; thus plantation biomass could supply about $43 \%$ of the total projected energy consumption in India in 2015.

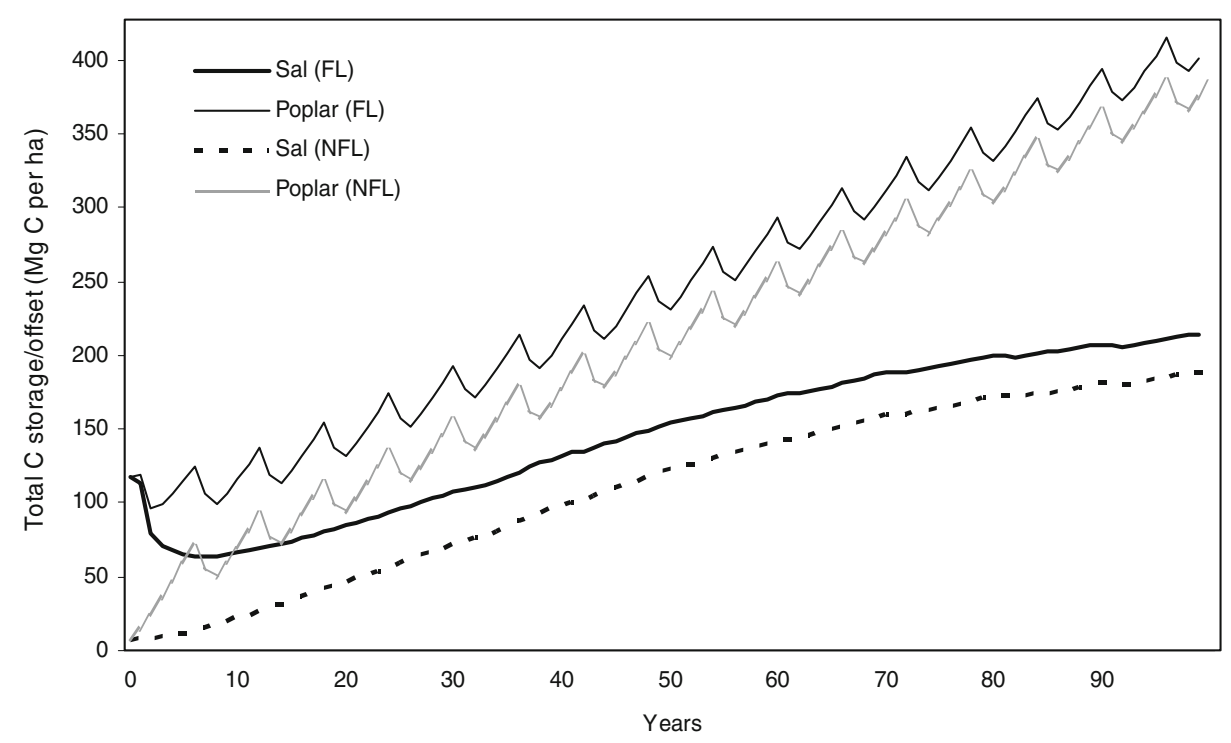

Fig. 5 Total Carbon sequestered/offset for different scenarios (a) Long rotation Sal afforestation, (b) Short rotation energy plantation for fossil fuel substitution 


\section{Discussion}

Several researchers have pointed out the relative carbon benefit of using land for growing short rotation plantations in addition to afforestation projects. Forest management integrated with bioenergy options has the potential for carbon mitigation in the land use sector. When short rotation plantations are used to produce bio-fuels to substitute fossil fuels, they can make an ongoing contribution to reducing net $\mathrm{CO}_{2}$ emissions. In addition, production of biomass for energy production in newly established short rotation plantations may take away pressure from existing forest land in which currently fuel wood is collected. Hence, bioenergy plantations may contribute to forest and biodiversity conservation. Conversion of agricultural lands to forest can result in much higher rates of sequestration due to increases in tree carbon in addition to soil carbon increases (Adams et al. 1999; Alig et al. 1997; Stavins 1999). IPCC special report on land use, land use change and forestry states that the potential for additional carbon sequestration on agricultural soils is related to how depleted the carbon stocks in the soil are at the start of a new carbon sequestering project (IPCC 2000). Our study results show that the soil carbon on forest lands displayed a rapid decrease in the initial 10 years from $118 \mathrm{Mg} \mathrm{C}^{-1}$ followed by a slow recovery and later stabilized at $60 \mathrm{Mg} \mathrm{C}^{-1}$. The slow increase could be mainly due to litter fall and other dead organic matter. Paul et al. (2003) suggested that soil organic carbon decreased at an average rate of $0.79 \mathrm{Mg} \mathrm{C} \mathrm{ha}{ }^{-1} \mathrm{yr}^{-1}$ during the first 10 years following afforestation and to increase at a rate of $0.46 \mathrm{Mg} \mathrm{C} \mathrm{ha} \mathrm{yr}^{-1}$ from 10 to 40 years. The average rate of soil organic carbon after 40 years was predicted to be $0.06 \mathrm{Mg} \mathrm{C} \mathrm{ha}^{-1} \mathrm{yr}^{-1}$. Paul et al. (2003) claimed that the initial decrease of soil organic carbon after afforestation was mainly due to soil disturbance by site preparation and low organic carbon input from a young forest stand. Findings from other studies also suggest that soils with high initial soil organic carbon contents generally showed losses in carbon immediately following afforestation (the first 5-10 years, Paul et al. 2002; Vesterdal et al. 2002), while soils with low initial soil organic carbon contents often exhibited gains of soil organic carbon (Bouwman and Leemans 1995; Garten 2002).

An earlier study by Hooda et al. (2007) estimated the $C$ mitigation potential of Eucalyptus under agro forestry system in the Uttarakhand state of India. The comparison of Eucalyptus for bioenergy at 6 year rotation and for carbon sink at 10 year rotation showed higher mitigation potential in bioenergy case. The net carbon abatement thus was $3.1 \mathrm{Mg} \mathrm{C}$ $\mathrm{ha}^{-1} \mathrm{yr}^{-1}$ under the bioenergy scenario and $1.96 \mathrm{Mg} \mathrm{C} \mathrm{ha}^{-1} \mathrm{yr}^{-1}$ under the agro-forestry system even though mean annual increment (MAI) of Eucalyptus in the latter case was $11.25 \mathrm{Mg} \mathrm{ha}^{-1} \mathrm{yr}^{-1}$. Our results are also comparable with the mitigation potential estimates from earlier studies in India. Hooda and Rawat (2006) estimated the carbon mitigation potential by 2010 in the range of $25 \mathrm{Tg} \mathrm{C}$ to $124.5 \mathrm{Tg} \mathrm{C}$ if plantation energy were substituted for fossil fuels. In case of marginal soils/wastelands, not currently under productive use, different species have been suggested to offer good prospects for energy plantations (Goel and Behl 1996; Baral and Guha 2004; Niu and Duiker 2006). Goel and Behl (1996) investigated Prosopis juliflora (Sw.) and Acacia nilotica (L.) for afforestation on alkaline soils in relation to tree age for establishing harvest rotation cycles. They suggested that these species were most suitable for short rotation fuel wood forestry programmes because of their high wood density, biomass yield, low ash and moisture content, and good heat of combustion at the juvenile stage. Coal is the mainstay of Indian energy sector and the rate of coal consumption in production of electricity, overall for India, is of the order of $0.77-0.85 \mathrm{Kg}$ per KWh (Raghuwanshi et al. 2006). For every Mg of fossil fuel burned, at least three quarters of $\mathrm{Mg}$ of carbon is released as $\mathrm{CO}_{2}$ and it has been found that $0.8-0.9 \mathrm{Kg}$ per $\mathrm{KWh} \mathrm{CO}_{2}$ is emitted in the Indian power sector (Raghuwanshi et al. 
2006). Dependence on coal-based electric power plants (accounting for $70 \%$ of power generation) is leading to environmental degradation; local (land degradation), regional (air, water and soil pollution) and global (greenhouse gas build-up leading to climate change) (Ravindranath et al. 2004). Among the renewable energy options, bioenergy technologies have been promoted for meeting rural electricity needs.

Van der Voet (in: Nabuurs and Mohren 1993) carried out an uncertainty analysis of the model CO2FIX for Norway spruce forest in central Europe. For the 32 independent inputs to the model, he found that for the total carbon stock, the average amounted to $316 \mathrm{Mg} \mathrm{C} \mathrm{ha}{ }^{-1}$, whereas the $95 \%$ confidence interval for the long term average (after 300 years simulation) ranged from 254 to $403 \mathrm{Mg} \mathrm{C}^{-1}$ which was found to be reasonable. The main uncertainty was caused by uncertainty over the soil organic matter dynamics and the carbon content of dry matter. Since the main input in our study was based on widely accepted growth and yield tables, the present study would probably give a comparable span in results. Although, the growth and yield tables are known to be based on rather old monitoring data which do not represent current site conditions, there are chances of carbon sequestration potential being underestimated. But on the other hand, yield tables also represent fully stocked forests which do not occur very often in practice (Nabuurs and Schelhaas 2002).

\section{Conclusion}

The most suitable option for a developing country like India lies in the use of non-forest lands for fast growing short rotation plantations for bioenergy. Reforestation of non-forest lands will prevent further degradation and also may provide continuous supply of biomass for energy use thereby replacing fossil fuels and reducing net carbon emissions. Among the two mitigation options i.e., storage and substitution, the best option to be adopted depends upon various factors. Substituting sustainably produced bioenergy for fossil fuels is a continuous way of mitigating greenhouse gas emissions. Based on the land use pattern in India, about 40 million ha of degraded and wasteland land (including 5 Mha next to rail tracks and highways) is available for plantation (Ravindranath and Balachandra 2009). India's wasteland is spread over different regions with different climatic conditions and also falls in the category of rain-fed or irrigated land. To cater to this variety, research is required to determine which particular species and plant variety which will give the maximum yield.

In case of already existing natural forests, carbon storage and preservation is the most appropriate method through improved management practices. Old growth natural forests serve as a global carbon sink, not just in the trees but also in the soils and these forests may accumulate large quantities over centuries (Luyssaert et al. 2008). When forests are considered only for carbon sequestration, long rotations give greater benefits for carbon storage in forest and product pools (Gercia et al. 2005; Kaul et al. 2010). Although there can be a net carbon storage in trees, soil, forest litter and wood products, all of these carbon pools achieve equilibrium and provide no carbon sequestration after a maximum value (Schlamadinger and Marland 1996). Evidently, clearing of old growth natural forests for plantation of short rotation crops for fossil fuel substitution is not advisable because the net effect is negative for a long period of time as most of the carbon will be lost to the atmosphere and it may take a long period to compensate this loss through substitution of fossil fuel use. However, in long run, energy plantations on the non-forest lands (referred to as agricultural and waste lands) may give higher net carbon benefit annually. The magnitude of the carbon benefit in the afforestation scenario is lowest at any time, as 
compared to fossil fuel substitution scenarios. Balancing the short and long term carbon benefits of two approaches i.e., sequestration and substitution depend on different parameters like growth rate, site conditions, substitution efficiency of bio-fuels etc. The difference in carbon balance is thus not only a matter of the management strategy but also reflects a difference in species selection and rates of forest growth. Our results suggest that short rotation plantations with higher growth rates result in greater net carbon benefit at the end of 100 year as compared to long rotation forests used for permanent carbon storage. At year 100 , a total of $216 \mathrm{Mg} \mathrm{C} \mathrm{ha}^{-1}$ is sequestered for afforestation, as opposed to offset of $412 \mathrm{Mg} \mathrm{C} \mathrm{ha}{ }^{-1}$ from carbon storage and fossil fuel substitution from short rotation poplar plantation. After a transient period, the bioenergy option mitigates around $3 \mathrm{Mg} \mathrm{C}^{-1} \mathrm{yr}^{-1}$ on forest land whereas it stabilizes at $4 \mathrm{Mg} \mathrm{C} \mathrm{ha}^{-1} \mathrm{yr}^{-1}$ on non-forest land, for poplar plantations.

Improvements in productivity will enhance benefits further. Also, in long run accumulated large stock is vulnerable to disturbances, pests etc, which might increase under projected climate change. With improved biomass productivity and efficient energy conservation, it is feasible to sustain a significant share of biomass in total energy use in India by utilizing even a small portion of degraded land for biomass plantation. Moreover, this energy plantation option will probably for India provide income to the owner, employment in the rural area, an alternative fuel source for replacing coal and reducing carbon emissions. It also may take away pressure on remaining forests, as fuel wood may become available from the energy plantations and does not need to be collected from the existing forests. The aim should be to take the short-term benefit and long-term view of the economics of bio-fuel plantation and provide a facilitating environment to the farmer, biofuel enterprises and researchers, so eventually, India may move forward towards energy independent nation.

Open Access This article is distributed under the terms of the Creative Commons Attribution Noncommercial License which permits any noncommercial use, distribution, and reproduction in any medium, provided the original author(s) and source are credited.

\section{References}

Adams DM, Alig RJ, McCarl BA, Callaway JM, Winnett SM (1999) Minimum cost strategies for sequestering carbon in forests. Land Econ 75(3):360-374

Alig RJ, Adams DM, McCarl BA, Callaway JM, Winnett SM (1997) Assessing effects of mitigation strategies for global climate change with an intertemporal model of the U.S. forest and agriculture sectors. Environ Resour Econ 9:259-274

Baral A, Guha GS (2004) Trees for carbon sequestration or fossil fuel substitution: the issue of cost vs. carbon benefit. Biomass Bioenergy 27:41-55

Berndes G, Hoogwijk M, Van den Broek R (2003) The contribution of biomass in the future global energy supply: a review of 17 studies. Biomass Bioenergy 25:1-28

Bouwman AF, Leemans R (1995) The role of forest soils in the global carbon cycle. In: Mcfee WF, Kelly FM (eds) Carbon forms and functions in forest soils. Soil Science Society of America, Masison, pp 503525

Carle J, Holmgren P (2008) Wood from planted forests - a global outlook 2005-2030. For Prod J 58(12):618

Dixon RK, Brown S, Houghton RA, Solomon AM, Trexler MC, Wisniewski J (1994) Carbon pools and flux of global forest ecosystems. Science 263:185-190

FAO (2008) Forests and energy, key issues. Working Paper No. 154. Rome 
FAO/FRA (2006) Global forest resources assessment 2005. Progress towards sustainable forest management. FAO, Rome

FSI (2003) State of the forest Report 2003. Forest Survey of India, Ministry of Environment and Forest, Govt. of India, Dehradun

Garten CT Jr (2002) Soil carbon storage beneath recently established tree plantations in Tennessee and South Carolina, USA. Biomass Bioenergy 23:93-102

Gercia JP, Lippke B, Comnick J, Manriquez (2005) An assessment of carbon pools, storage, and wood products market substitution using life cycle analysis results. Wood and Fibre Science, 37 Corrim special issue, 2005, pp 140-148

Global Carbon Project (GCB) (2008) Carbon budget and trends 2007, www.globalcarbonproject.org

Goel VL, Behl HM (1996) Fuel wood quality of promising tree species for alkaline soil sites in relation to tree age. Biomass Bioenergy; 10:57-61

Gupta S, Ravindranath NH (1997) Financial analysis of cooking energy options for India. Energy Conservation and Management 38(18):1869-1876

Hooda N, Rawat VRS (2006) Role of bio energy plantation for carbon dioxide mitigation with special reference to India. Mitig Adapt Strat Glob Change 11:445-467

Hooda N, Gera M, Andrasko K, Sathaye JA, Gupta MK, Vasistha HB, Chandran M, Rassaily SS (2007) Community and farm forestry climate mitigation projects: case studies from Uttaranchal, India. Mitig Adapt Strategies Glob Chang 12(6):1099-1130

Intergovernmental Panel on Climate Change (IPCC) (2000) In: Watson RT, Noble IR, Bolin B, Ravindranath NH, Verardo DJ, Dokken D (eds) Special report on land use, land use change and forestry. Science, Cambridge University Press, Cambridge

IPCC (2001) Climate change 2001: the scientific basis. IPCC third assessment report, Working group I, Technical Summary. Cambridge University Press, Cambridge

IPCC (2007) Climate change 2007: the scientific basis: IPCC fourth assessment report, Working Group I. Available online at http://www.ipcc.ch

Kaul M, Mohren GMJ, Dadhwal VK (2010) Carbon sequestration potential of selected Indian tree species. (Submitted to Mitigation and Adaptation Strategies for Global Change).

Liski J, Palosuo T, Sievänen R (2005) Carbon and decomposition model Yasso for forest soils. Ecol Model 189:168-182

Luyssaert S, Schulze ED, Borner A, Knohl A, Hessenmoller D, Law BE, Ciais P, Grace J (2008) Old growth forests as global carbon sinks. Nature 455:213-215

Marland G, Schlamadinger B (1997) Forests for carbon sequestration or fossil fuel substitution? A sensitivity analysis. Biomass Bioenergy 13(6):389-397

Masera OR, Garza-Caligaris JF, Kanninen M, Karjalainen T, Liski J, Nabuurs GJ, Pussinen A, de Jong BHJ, Mohren GMJ (2003) Modelling carbon sequestration in afforestation, agroforestry and forest management projects: the CO2FIX V.2 approach. Ecol Model 164:177-199

Nabuurs GJ, Mohren GMJ (1993) Carbon fixation through forestation activities: a study of the carbon sequestering potential of selected forest types, commissioned by the Foundation Face. Institute for Forestry and Nature Research, Wageningen. IBN Research Report 93/4

Nabuurs GJ, Schelhaas MJ (2002) Carbon profiles of forest types across Europe assessed with CO2FIX. Ecol Indicators 1:213-223

Niu X, Duiker SW (2006) Carbon sequestration potential by afforestation of marginal agricultural land in the Midwestern U.S. For Ecol Manag 223:415-427

Paul KI, Polglase PJ, Nyakuengama JG, Khanna PK (2002) Change in soil carbon following afforestation. For Ecol Manag 168:241-257

Paul KI, Polglase PJ, Richards GP (2003) Predicted change in soil carbon following afforestation or reforestation, and analysis of controlling factors by linking a $\mathrm{C}$ accounting model (CAMFor) to models of forest growth (3PG), litter decomposition (GENDEC) and soil C turnover (RothC). For Ecol Manag 177:485-501

Raghuvanshi SP, Chandra A, Raghav AK (2006) Carbon dioxide emissions from coal based power generation in India. Energy Conservation and Management 47:427-441

Ravindranath NH, Balachandra P (2009) Sustainable bio energy for India: technical, economic and policy analysis. Energy. doi:10.1016/j.energy.2008.12.012

Ravindranath NH, Somashekar HI, Dasappa S, Reddy JCN (2004) Sustainable biomass power for rural India: case study of biomass gasifier for village electrification. Current Sci 87(7):10

Rawat VRS, Kishan J (2008) Forest conservation-based, climate change-mitigation approach for India. Int For Rev 10(2):269-280 
Schelhaas MJ, Esch P Van, Groen TA, De Jong BHJ, Kanninen M, Liski J, Masera O, Mohren GMJ, Nabuurs GJ, Palosuo T, Pedroni L, Vallejo A, Vilen T (2004) CO2FIX v. 3.1-A framework for quantifying carbon sequestration in forest ecosystems. Wageningen, Alterra, Alterra rapport 1068

Schlamadinger B, Marland G (1996) The role of forest and bioenergy strategies in the global carbon cycle. Biomass Bioenergy 10:275-300

Stavins RN (1999) The costs of carbon sequestration: a revealed-preference approach. Am Econ Rev 89:994-1009

Sudha P, Somashekhar HI, Rao S, Ravindranath NH (2003) Sustainable biomass production for energy in India. Biomass Bioenergy 25:501-515

Takeshita T (2009) A strategy for introducing modern bio energy into developing Asia to avoid dangerous climate change. Appl Energy 86:s222-s232

Tewari DN (1995) A monograph on Sal. Vedam, India

Vesterdal L, Ritter E, Gundersen P (2002) Change in soil organic carbon following afforestation of former arable land. For Ecol Manag 169:137-147

Walker N, Bazilian M, Buckley P (2009) Possibilities of reducing CO2 emissions from energy-intensive industries by the increased use of forest derived fuels in Ireland. Biomass Bioenergy 33:1229-1238 